Disaster Preparedness

Need for inclusion in undergraduate nursing education

"Susan Achora and Joy K. Kamanyire

$$
\begin{aligned}
& \text { التأهب لبحابهة الكوارث } \\
& \text { ضرورة إدخاله في منهج التمريض التعليمي للدراسات الجامعية }
\end{aligned}
$$

سوزان أكورا و جوي كباسيندي كاماناير

ABSTRACT: With the increasing global frequency of disasters, the call for disaster preparedness training needs to be reinforced. Nurses form the largest group of the healthcare workforce and are often on the frontline in disaster management. Therefore, nurses should be adequately equipped with the knowledge and skills to respond to disasters, starting from their pre-service training to their in-service professional training. However, the inclusion of disaster preparedness education in undergraduate nursing curricula is minimal in most countries. The purpose of this article is to highlight the current state of nursing education and training in disaster management, both generally and in Oman. The significance of disaster preparedness training and recommendations for its inclusion in nursing practice and education are also discussed.

Keywords: Disasters; Disaster Planning; Nursing Education; Students; Health Personnel; Oman.

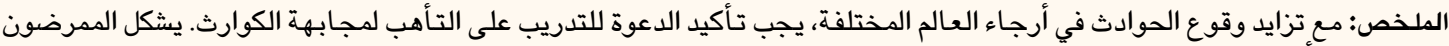

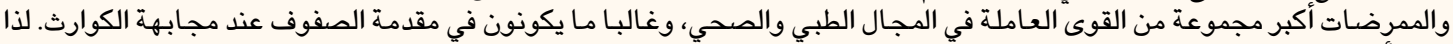

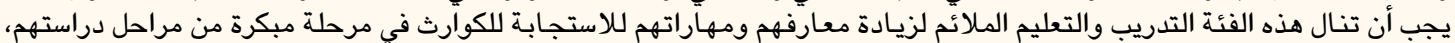

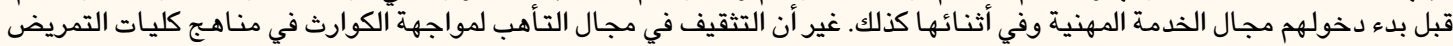

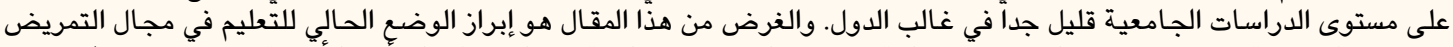

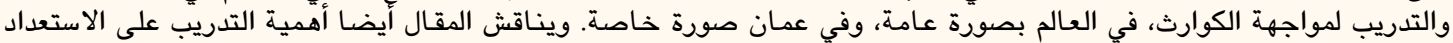

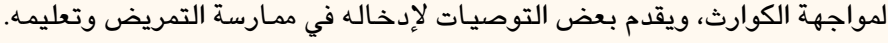

مفتاح الكلمات: الكوارث؛ تخطيط الكوارث؛ تعليم التمريض؛ الطلاب؛ العاملين بالصحة؛ عمان.

$\mathrm{T}$ He United Nations Office for Disaster Risk Reduction defines a disaster as a "serious disruption of the functioning of a community or society involving widespread human, material, economic or environmental losses and impacts which exceeds the ability of the affected community and society to cope using its own resources." Disasters can be natural or man-made and range from localised events to large-scale public health emergencies. The occurrence of a disaster is unpredictable and may result in chaos, mass casualties and destruction of property with devastating long-term social, physical, psychological, environmental and economic consequences that affect the health of a population and strain the capacity of the healthcare system. ${ }^{1}$ Globally, there has been a steady increase in the magnitude and frequency of disasters and public health emergencies in recent years. In the last decade, there has been an estimated $60 \%$ increase in disasters worldwide in which an estimated two million people lost their lives, 4.2 million were injured, 33 million were left homeless and three billion were otherwise affected. ${ }^{2,3}$ Climate change is thought to play a role in the larger number and greater impact of natural disasters; as a result, countries worldwide are encouraged to prepare accordingly. ${ }^{4}$ Disasters have increasingly become a global concern as an event in one region can have a great impact on another; as such, no nation, region or community is immune. For instance, the recent Ebola outbreak in West Africa put major cities across the globe on alert. ${ }^{5,6}$

Disasters demand concrete plans for management. The International Council of Nurses (ICN) Disaster Management Continuum Model has four main components: mitigation, preparedness, response and recovery. ${ }^{7}$ The aim of the model is to reduce the impact on lives and infrastructure, enhance recovery and build community resilience to disasters. ${ }^{7}$ The Hyogo Framework for Action, which has been endorsed by the United Nations General Assembly, highlights 
strengthening disaster preparedness at all levels as a priority for effective disaster management. ${ }^{8}$ Disaster preparedness involves planning and preparation to effectively respond to any disaster situation. This includes implementing capacity development, coordinating the participation of responsible organisations, individuals and volunteers and ensuring that all personnel are equipped for response. ${ }^{8}$

\section{Role of the Nurse in Disasters}

When disasters occur, members of the healthcare professions are often among the first individuals to respond to the situation. As such, the disaster preparedness training of all healthcare professionals is essential to maintaining an efficient healthcare system in the midst of a disaster, particularly in view of the potentially widespread nature and complex environment of this type of incident. ${ }^{2}$ However, disaster preparedness training in most countries is based in specialised hospitals, public health schools or medical schools. ${ }^{9}$ Surveys of recent global disasters have noted persistent gaps in the education, training and abilities of healthcare professionals in emergency situations. ${ }^{7,10}$ In response to these deficiencies, several organisations and groups based mainly in developed countries have begun to develop competency-based education and training for members of the healthcare workforce and other responders. ${ }^{7}$

Due to the recent global increase in disasters, the World Health Organization (WHO) recommends that all countries, no matter how frequently they experience disasters, consider training their healthcare professionals to respond to disasters as a national and local priority. ${ }^{11}$ As nurses make up the majority of healthcare providers, they represent an indispensable workforce during disasters. The fundamental attributes of the nursing practice are to provide care to the injured or ill, assist individuals and families to deal with physical and emotional issues and work to improve health and well-being within the community. These attributes require competent nurses who are ready to respond in all situations, including in the event of a disaster. Nurses must be able to adapt their skills from focusing on individuals to large numbers of patients, both in their delivery of lifesaving and emergency care and in the maintenance of public health. ${ }^{7,9}$ Therefore, disaster training for nurses is vital. Nurses must be involved in all phases of disaster planning in order to increase their understanding of their role and expected contributions in response to a disaster.

\section{Disasters and Disaster Management in Oman}

Oman has a history of frequent tropical storms which can have devastating effects on lives and infrastructure, the most recent of which was Cyclone Gonu in 2007. ${ }^{12}$ In addition, Oman is at risk of emerging public health emergencies such as the influenza A virus subtype haemagglutinine-1 neuraaminidase-1 (swine flu) and coronavirus (Middle East respiratory syndrome), among others. The National Disaster Management Committee coordinated by the Oman National Committee for Civil Defence has standards for health emergency plans which involve prevention, mitigation, preparedness and response measures to both natural and man-made disasters. ${ }^{13}$

Nevertheless, emergency management in Oman is still lacking and large gaps in disaster management have been reported following major disasters; according to interviews with health personnel, they were often confused, disoriented or left to work without prior guidelines during Cyclone Gonu. ${ }^{12}$ In addition, infrequent training and unclear staff training modalities were found to exist in healthcare disaster plans designed and implemented by the Ministry of Health $(\mathrm{MOH})$ in Oman. ${ }^{14}$

\section{Role of Nursing Undergraduate Curricula in Disaster Preparedness}

Higher education institutions are capable of making great contributions to all phases of disaster management. First, these institutions can inculcate a culture of disaster preparedness and mitigation by developing training curricula, promoting educational opportunities and raising awareness of institutional disaster management plans. Second, academic institutions can conduct relevant research and develop capacity-building programmes for healthcare workers and those involved in humanitarian work. ${ }^{15}$ These measures would create a wealth of resources that could be utilised in national preparedness and response systems through academicpublic health partnerships. ${ }^{16}$

Disaster preparedness is a critical component of undergraduate education for health professionals. Students must be adequately educated to successfully carry out their roles in disasters as a professional requirement. ${ }^{9}$ As such, core competencies must be established and function effectively. In 2009, the WHO and the ICN developed the Framework of Disaster Nursing Competencies; all nurses 
worldwide are expected to be able to demonstrate the outlined competencies, thus providing an avenue to adequately prepare nurses for their future roles in disaster management. ${ }^{5}$ However, many health academic institutions around the world lack disaster preparedness curricula and have no developed competencies for students in health professions. ${ }^{7,17,18}$

\section{Global Trends in Disaster Preparedness Education}

In the USA, education on preparing for disasters was introduced within nursing curricula in the early 1970s but was then gradually removed. ${ }^{7}$ It wasn't until the late 1990s that the increasing involvement of nurses in disaster response situations strengthened the need to once again include disaster nursing education in the curriculum. ${ }^{7}$ In 2003, the National Student Nurses' Association in the USA passed resolutions to include disaster preparedness content in the nursing curricula of all nursing schools. ${ }^{19}$ A few other nursing programmes worldwide have adopted the American curriculum. ${ }^{20}$ In the UK, as one of the requirements for nursing education pre-registration, nurses joining adult health specialties are mandated to recognise their role in disaster management, major incidents and public health emergencies and to respond appropriately according to their level of competence. ${ }^{21}$

Disaster nursing education for undergraduate students was recently introduced in 44 nursing schools in China. ${ }^{22}$ In contrast, less than half of the nursing education programmes in Japan included disaster nursing courses in 2009.7 Universities in Hong Kong and Australia did not include disaster content in their undergraduate nursing curricula in 2013.17,18 There is little information available on disaster training in nursing curricula among universities in Africa or the Middle Eastern region, apart from certain universities in Iran, Turkey and Jordan. ${ }^{23-25}$

\section{Disaster Preparedness Education in Oman}

Currently, there is no information on the availability of disaster nursing content in the undergraduate curriculum for nursing students in Oman. Diplomalevel training of nurses in Oman began in the early 1970s and the first baccalaureate nursing programme commenced in 2002. ${ }^{26}$ Currently, two universities in Oman provide degree programmes and the $\mathrm{MOH}$ plans to encourage nursing institutions offering diploma programmes to upgrade their curricula to the baccalaureate level. ${ }^{26,27}$ However, there is no documented evidence that disaster preparedness is or will be included within the core competencies of either diploma or undergraduate nurses in Oman. It can therefore be assumed that disaster training for nursing students in Oman is suboptimal; critically, this may translate into a generation of future nurses who are ill-equipped to handle disasters.

\section{Barriers to Implementing Disaster Preparedness Education}

Several barriers exist to the implementation of disaster training for student nurses. For a long time, disaster preparedness training was reserved only for nurses practicing in emergency departments or was offered only as a specialised post-basic course..$^{28}$ Additionally, existing nursing curricula in many countries are already at maximum capacity without the addition of further modules on disaster preparedness. ${ }^{29}$ To cope with this, there is a need to review nursing curricula to identify areas where disaster concepts can be integrated into current courses within nursing programmes. ${ }^{20}$ Furthermore, teaching faculty may lack the knowledge and confidence to teach disaster content. In the USA, the National League for Nurses reported that $75 \%$ of faculty teaching 348 nursing programmes were poorly prepared to teach disaster preparedness content. ${ }^{29}$

\section{Significance of Disaster Preparedness Training for Undergraduate Students}

In general, the number of undergraduate programmes preparing student nurses for disaster management is still limited in many countries, resulting in professional nurses with limited competencies to participate effectively during a disaster. ${ }^{7,20}$ Various international regulatory bodies have called for the inclusion of disaster content in nursing education at all levels. ${ }^{7}$ Introducing disaster nursing content at the undergraduate level will not only increase the capacity of the health workforce to respond but will provide graduates entering the workforce with a foundation which can be developed further through in-service training and continuing professional development (CPD) programmes, thus saving resources..$^{20}$ Effective prior training also ensures the safety and health of healthcare workers and responders during a disaster. ${ }^{9}$ Additionally, it may also improve the willingness of students to help during a disaster; undergraduate nursing students may be called upon during large-scale disasters to boost the capacity of practicing nurses 
and these students must therefore possess the basic knowledge and skills of disaster nursing. ${ }^{17,18}$ Student nurses trained in disaster management could also assist in community education programmes as part of a community disaster preparedness health initiative. ${ }^{29}$

\section{Recommendations for Improving Disaster Preparedness Education}

In preparation for disasters, nurses must be able to assess their own limitations, knowledge and skills. Integrating disaster management courses into nursing curricula and offering CPD courses in disaster management would prepare nurses for emergency situations. ${ }^{2}$ The development of the teaching faculty through partnerships with agents involved in training personnel for disaster management is a step in the right direction to ensure proficiency in the undergraduate teaching of disaster preparedness. ${ }^{20}$ The WHO and ICN Framework of Disaster Nursing Competencies could be adopted by universities to underpin undergraduate nursing curriculum content. ${ }^{7}$

Currently, there is no evidence in the literature of a national action to prepare nurses for disasters in Oman. Academic institutions and the $\mathrm{MOH}$ should work together to develop a national framework for disaster training in Oman. This will provide a more consistent approach and standardisation of nursing education programmes in order to ensure that subsequent generations of nurses have been reliably and consistently trained in disaster management. The regulatory authority of professional nurses in Oman needs to ensure that all nursing graduates meet the $\mathrm{WHO} / \mathrm{ICN}$ disaster competencies by including disaster nursing as a mandatory component in nursing curricula. ${ }^{7}$ The Oman Medical Specialty Board, as a body responsible for CPD in Oman, should include evidence-based disaster preparedness as a mandatory course for all health professionals in the country. National disaster plans are needed, with clearly specified steps to be undertaken and transparent guidelines to be followed in the event of an emergency. Furthermore, educational institutions should implement simulated disaster drills to encourage practicing nurses to maintain competence in this area.

\section{Conclusion}

Given the increasing global frequency of disasters, it is critical that nurses are able to effectively respond to disaster situations. However, many health professionals still lack the necessary knowledge and skills. There is therefore an urgent need to include disaster preparedness content in undergraduate nursing curricula, both globally and within Oman. The WHO and ICN Framework of Disaster Nursing Competencies is recommended for inclusion within nursing education. As part of their CPD process, practicing nurses in Oman should also undergo regular evidence-based simulated training and skill updates.

\section{References}

1. The United Nations Office for Disaster Risk Reduction. Terminology. From: www.unisdr.org/eng/library/lib-terminology -eng\%20home.htm Accessed: Jul 2015.

2. International Federation of Red Cross and Red Crescent Societies. World disasters report 2007: Focus on discrimination. From: www.ifrc.org/PageFiles/99876/WDR2007-English.pdf Accessed: Jul 2015.

3. Centre for Research on the Epidemiology of Disasters. The International Disaster Database: Disasters trends index. From: www.emdat.be/disaster_trends/index.html Accessed: Jul 2015.

4. Quaile I. More natural disasters due to climate change? From: www.dw.com/en/more-natural-disasters-due-to-climatechange/a-4598063 Accessed: Jul 2015.

5. Matua GA, Van der Wal DM, Locsin RC. Ebolavirus and haemorrhagic syndrome. Sultan Qaboos Univ Med J 2015; 15:e171-6.

6. European Centre for Disease Prevention and Control. Ebola outbreak in West Africa. From: www.ecdc.europa.eu/en/ healthtopics/ebola_marburg_fevers/Pages/ebola-outbreakwest-africa.aspx Accessed: Jul 2015.

7. International Council of Nurses and World Health Organization Western Pacific Region. ICN Framework of Disaster Nursing Competencies. From: www.wpro.who.int/hrh/documents/icn_ framework.pdf Accessed: Jul 2015.

8. The United Nations Office for Disaster Risk Reduction. Hyogo Framework for Action 2005-2015: Building the resilience of nations and communities to disasters. From: www.unisdr.org/ we/inform/publications/1037 Accessed: Jul 2015.

9. Chapman K, Arbon P. Are nurses ready? Disaster preparedness in the acute setting. Australas Emerg Nurs J 2008; 1:135-44. doi: 10.1016/j.aenj.2008.04.002.

10. Arbon P, Bobrowski C, Zeitz K, Hooper C, Williams J, Thitchener J. Australian nurses volunteering for the SumatraAndaman earthquake and tsunami of 2004: A review of experience and analysis of data collected by the Tsunami Volunteer Hotline. Australas Emerg Nurs J 2006; 9:171-8. doi: 10.1016/j.aenj.2006.05.003.

11. World Health Organization. Emergency and disaster risk management for health. From: www.who.int/hac/techguidance/ preparedness/en/ Accessed: Jul 2015.

12. Al-Shaqsi S. Care or cry: Three years from Cyclone Gonu - What have we learnt? Oman Med J 2010; 25:162-7. doi: $10.5001 /$ omj.2010.50.

13. Al-Shaqsi SZ. Emergency management in the Arabian Peninsula: A case study from the Sultanate of Oman. From: www.training. fema.gov/hiedu/downloads/compemmgmtbookproject/ comparative\%20em\%20book\%20-\%20em\%20in\%20oman.doc Accessed: Jul 2015.

14. Al-Shaqsi S, Gauld R, McBride D, Al-Kashmiri A, Al-Harthy A. The state of healthcare disaster plans in New Zealand and the Sultanate of Oman: An international comparative analysis. Adv Emerg Med 2014; 2014:758728. doi: 10.1155/2014/758728. 
15. Dunlop AL, Logue KM, Isakov AP. The engagement of academic institutions in community disaster response: A comparative analysis. Public Health Rep 2014; 129:87-95.

16. Galliara M, Prabhawalkar A. Disaster management and role of academic institutions. Soc Work Chron 2012; 1:1-29.

17. Cusack L, Arbon P, Ranse J. What is the role of nursing students and schools of nursing during disaster? A discussion paper. Collegian 2010; 17:193-7. doi: 10.1016/j.colegn.2010.09.006.

18. Usher K, Mayner L. Disaster nursing: A descriptive survey of Australian undergraduate nursing curricula. Australas Emerg Nurs J 2011; 14:75-80. doi: 10.1016/j.aenj.2011.02.005.

19. National Student Nurses' Association. Resolutions 2003. From: www.nsna.org/Portals/0/Skins/NSNA/pdf/Resolution2003.pdf Accessed: Dec 2015.

20. Halstead JA. When disaster strikes: Are you and your nursing students prepared? Nurs Educ Perspect 2013; 34:213. doi: 10.5480/1536-5026-34.4.213.

21. Nursing \& Midwifery Council. Standards for pre-registration nursing education. From: www.nmc.org.uk/globalassets/site documents/standards/nmc-standards-for-pre-registrationnursing-education.pdf Accessed: Jul 2015.

22. Chan SS, Chan WS, Cheng Y, Fung OW, Lai TK, Leung AW, et al. Development and evaluation of an undergraduate training course for developing International Council of Nurses disaster nursing competencies in China. J Nurs Scholarsh 2010; 42: 405-13. doi: 10.1111/j.1547-5069.2010.01363.x.
23. Al Khalaileh MA, Bond E, Alasad JA. Jordanian nurses' perceptions of their preparedness for disaster management. Int Emerg Nurs 2012; 20:14-23. doi: 10.1016/j.ienj.2011.01.001.

24. Zarea K, Beiranvand S, Sheini-Jaberi P, Nikbakht-Nasrabadi A. Disaster nursing in Iran: Challenges and opportunities. Australas Emerg Nurs J 2014; 17:190-6. doi: 10.1016/j. aenj.2014.05.006.

25. Öztekin SD, Larson EE, Yüksel S, Altun Uğraş G. Undergraduate nursing students' perceptions about disaster preparedness and response in Istanbul, Turkey, and Miyazaki, Japan: A crosssectional study. Jpn J Nurs Sci 2015; 12:145-53. doi: 10.1111/ jjns.12058.

26. Minority Nurse. Professional nursing in Oman. From: www. minoritynurse.com/professional-nursing-in-oman/ Accessed: Jul 2015.

27. Ghosh B. Health workforce development planning in the Sultanate of Oman: A case study. Hum Resour Health 2009; 7:47. doi: 10.1186/1478-4491-7-47.

28. Nyamathi AM, King M, Casillas A, Gresham LS, Mutere M. Nurses' perceptions of content and delivery style of bioterrorism education. J Nurses Staff Dev 2007; 23:251-9. doi: 10.1097/01. NND.0000300843.97222.dc.

29. Weiner E, Irwin M, Trangenstein P, Gordon J. Emergency preparedness curriculum in nursing schools in the United States. Nurs Educ Perspect 2005; 26:334-9. doi: 10.1043 /1536-5026(2005)026[0334:EPCINS]2.0.CO;2. 